\title{
Trends, Challenges and Opportunities in Advanced Solar Cells Technologies and PV Market
}

\author{
Laurentiu Fara ${ }^{* 1,2}$ Alexandru Diaconu ${ }^{1}$ \\ and Florin Dragan ${ }^{1}$ \\ ${ }^{1}$ Polytechnic University of Bucharest (PUB), Splaiul Independentei 313, Sector 6, \\ RO 060032 Bucharest, Romania \\ ${ }^{2}$ Academy of Romanian Scientists (AOSR), Splaiul Independentei 54, Sector 5 , \\ RO 050094 Bucharest, Romania \\ E-mail:lfara@renerg.pub.ro; adiaconu86@gmail.com; \\ diaconu_alex@hotmail.com; florin.dragan@sdettib.pub.ro \\ ${ }^{*}$ Corresponding Author
}

Received 14 May 2016; Accepted 3 August 2016;

Publication 22 September 2016

\begin{abstract}
Selected results in modelling and numerical simulation of advanced solar cells obtained by the Solar Energy Group from the Faculty of Applied Sciences of PUB (SEG-FSA) are highlighted. The opportunities for PV development together with the world PV market performances, relevant European PV market features and the forecasts until 2018 are discussed.
\end{abstract}

Keywords: Trends, challenges, opportunities, advanced solar cells, modelling and simulation, PV market, forecasting.

\section{Introduction}

The speed and scale of the current development of the photovoltaic (PV) industry in the last 30 years is extremely surprising and remarkable [1]. It was accompanied by the rapid dropping of the PV prices. The PV revolution has

Journal of Green Engineering, Vol. 5, 157-186.

doi: 10.13052/jge1904-4720.5350

(c) 2016 River Publishers. All rights reserved. 
reflected the microelectronic revolution in several ways. One of its attractive features is represented by the international contributions in PV industry and technology. There is a fantastic leap between the first PV laboratories in fundamental physics and chemistry from Europe since 60 years ago and the modern industrial PV laboratories and manufacturing all over the world (Europe, USA, Japan, China etc.). To understand how it was possible to reach this impressive level of development, it would be necessary to consider the talent of the researchers who succeeded to introduce lower cost abundant PV materials, new methods of photon management, and new paradigms in PV conversion.

Based on these ideas, the present paper was organized in the following sections:

- Advanced Solar Cells Technologies

- Results obtained by the Solar Energy Group from the Faculty of Applied Sciences of PUB (SEG-FSA)

- Modelling and Simulation for Advanced Solar Cells - Global Vision

- World PV Market Development

- High Opportunities for PV Development

- Relevant European PV Market in 2014

- Forecasts of PV in Europe until 2019

- Conclusions and Prospects

\section{Advanced Solar Cells Technologies}

According to the World Energy Vision 2100 recommended by German Advisory Council on Global Change [2], Solar Photovoltaic electricity can become a major source of energy with approx. 20\% in 2050 and $70 \%$ in 2100 (see Figure 1).

The main performances of different types of solar cells including: conversion efficiency, area, fill factor (FF) and main electric parameters (short circuit current $\mathrm{J}_{\mathrm{sc}}$ and open circuit voltage $\mathrm{V}_{\mathrm{oc}}$ ) are presented in the Table 1 . We could remark that compound multi-junction and concentrator solar cells together with CdTe solar cells and CIGS (CulnGaSe 2 ) solar cells are expected to have high efficiency. At the same time the development of heterojunction Si solar cells with transparent conductive oxide layers has very good perspectives.

The cost drop of PV modules is essential for the implementation of large scale photovoltaic systems. The comparison of PV module price for different types of solar cells is presented in the Figures 2, 3 and 4. 
WBGU's World Energy Vision 2100
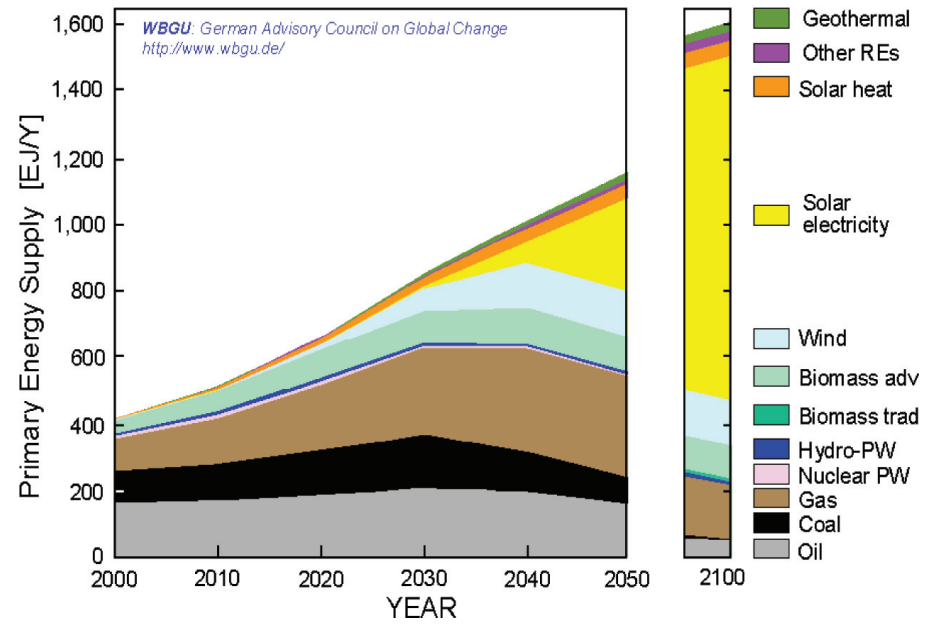

Figure 1 Transforming the global energy mix: Reserve of primary energy by 2050/2100 [2].

Figure 5.2: Average monthly solar PV module prices by technology and manufacturang country sold in Europe, 2009 то 2014

2014 USD/W

4

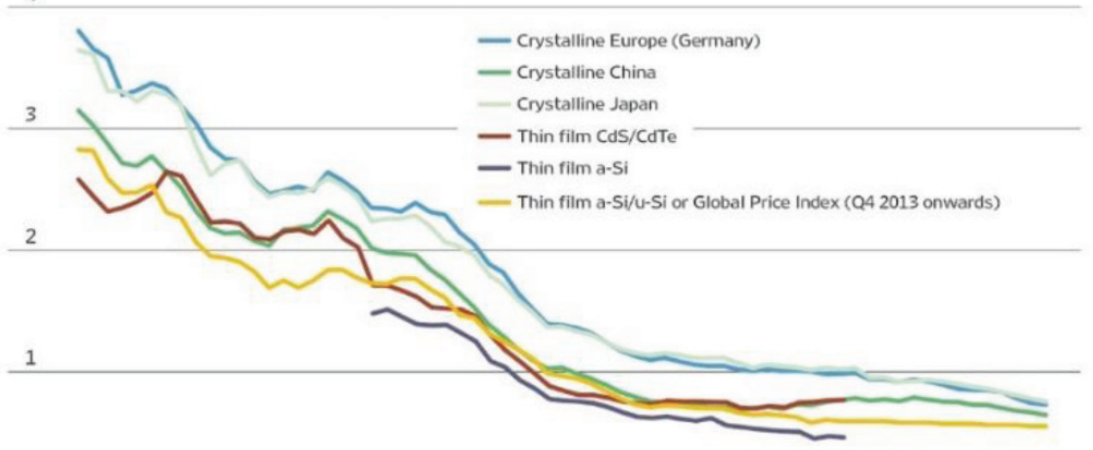

May 09 Nov 09 May 10 Nov 10 May 11 Nov 11 May 12 Nov 12 May 13 Nov 13 May 14 Nov 14

Figure 2 Average monthly PV module prices in Europe, 2009 to 2014 [4]. 


\section{RENEWABLE POWER GENERATION COSTS IN 2014 \\ QOIRENA}

:

Figure 2.2: CumUlative global SOLAR PHOTOVOLtAIC DEPLOYMENT AND SOLAR PHOTOVOLTAIC MOdULE PRICES, 2000 TO 2014

2014 USD/Wp

GW

5

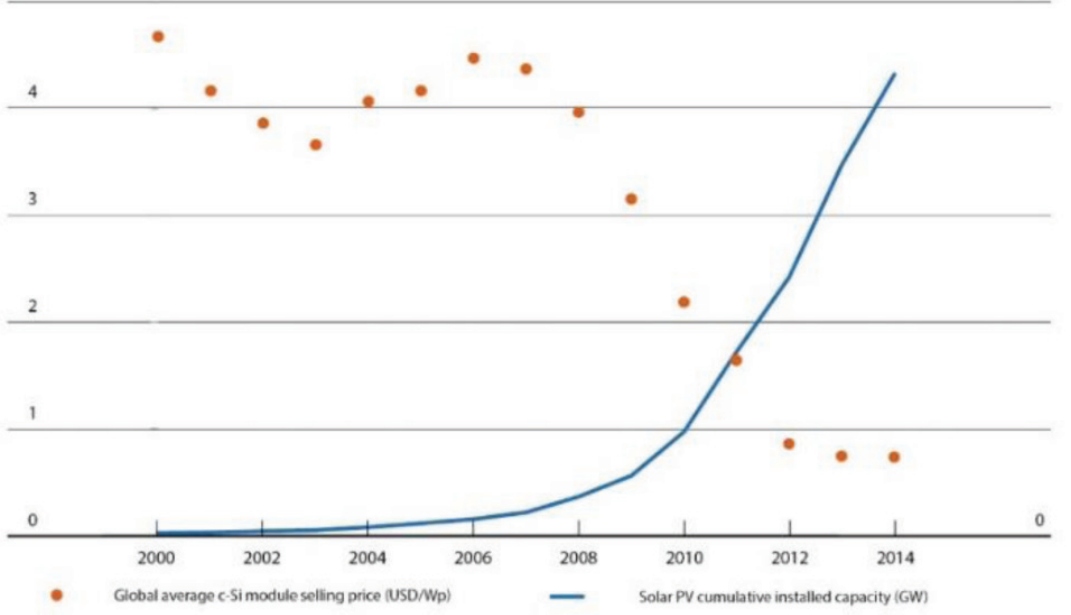

Sources. IRENA and pvXchange, 2014

Figure 3 Cumulative global PV development and PV module prices, 2000 to 2014 [4].

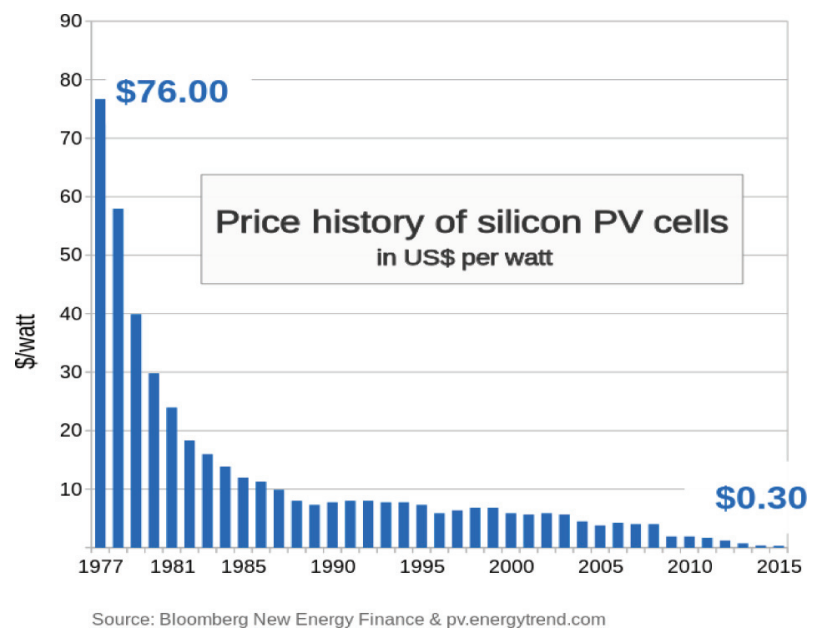

Figure 4 Evolution of price for silicon PV cells [5]. 


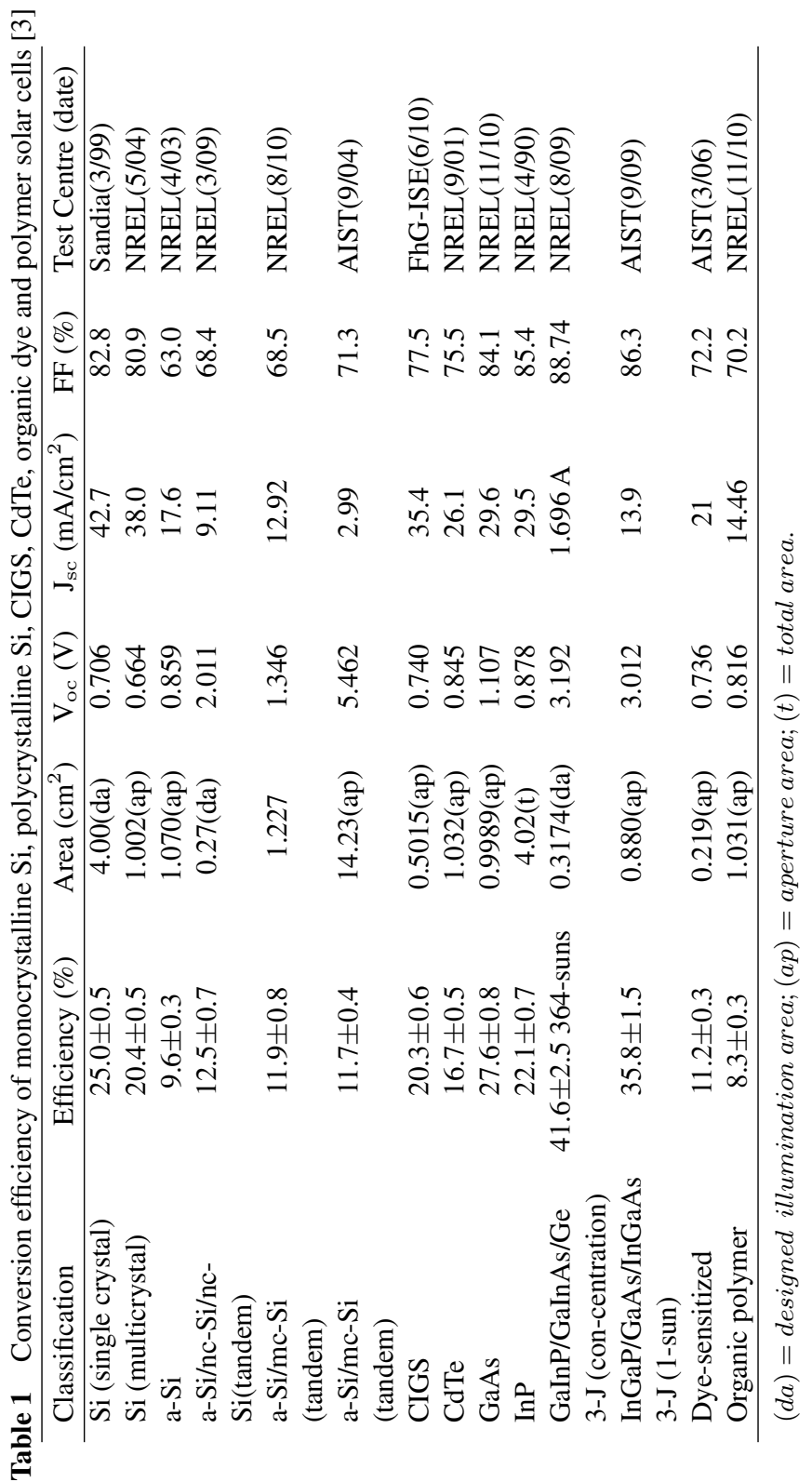




\section{Selected Results Obtained by the Solar Energy Group from University Politehnica of Bucharest, Faculty of Applied Sciences (SEG-FSA)}

The Solar Energy Group from the Faculty of Applied Sciences of University Politehnica of Bucharest (SEG-FSA) developed contributions in electrical and optical modelling and simulation of advanced solar cells, like: Multiple Quantum Well Solar Cells (MQW), Dye-Sensitized Solar Cells (DSSC), Polymer Solar Cells and Thin Film Solar Cells. In addition, forecasting of photovoltaic systems by estimation of solar radiation has also been studied.

\subsection{Quantum Well Solar Cells (MQW)}

\subsubsection{New results in optical modelling of quantum well solar cells - Silvian Fara, Paul Sterian, Laurentiu Fara, Mihai lancu, and Andreea Sterian, International Journal of Photoenergy, Volume 2012, DOI:10.1155/ 2012/810801 [6]}

This article brought further advancements to the quantum well solar cell concept proposed by Keith Barnham [7].

(i) There were studied several MQW solar cells configurations for optimized values of the optical parameters (reflectance, refraction index, and absorption), so the conversion efficiency could be improved.

(ii) Although in our study, we have considered only rectangular quantum wells, the hybrid model allows computing the levels of the quantum well, regardless of its form.

(iii) It was evaluated the quantum well number effect over the refraction index and reflection losses by evaluation of the optimal quantum well structure number.

(iv) The proposal reflectance model could be used to determine the variation effect of the quantum well number over the refraction index.

(v) It was developed an absorption coefficient model [8], in order to be used for studying the simulation of the MQW solar cells [9].

(vi) It was obtained the internal quantum efficiency for the absorption process between the confining levels [10].

(vii) The results generated by the model simulator are in agreement with the experimental ones [11, 12]. 


\subsubsection{Quantum mechanical effects analysis of nanostructured solar cell model - Andrei Badea, Florin Dragan, Laurentiu Fara and Paul Sterian, Proceedings WREC 2015, Journal of Renewable Energy and Environmental Sustainability, 1, 3, 2016, DOI: 10.1051/rees/2016003 [13]}

The quantum mechanical effects resulted from the inclusion of nanostructures, represented by quantum wells and quantum dots, in the i-layer of an intermediate band solar cell are analysed.

(i) The role of these specific nanostructures in the increasing of the solar cells efficiency is discussed $[14,15]$.

(ii) Following the placement of InAs quantum wells in the i-layer of a GaAs $\mathrm{p}-\mathrm{i}-\mathrm{n}$ cell, there are analysed the quantum confined regions and determined the properties of the eigenstates located therein.

(iii) The electroluminescence that occurs due to the nanostructured regions is simulated and discussed [16].

\subsection{Dye-Sensitized Solar Cells (DSSC)}

\subsubsection{Numerical Procedure for Optimizing Dye-Sensitized Solar Cells - Mihai Razvan Mitroi, Laurentiu Fara and Magdalena Lidia Ciurea, Journal of Nanomaterials, Volume 2014, Article ID 378981, 6 pp, http://dx.doi.org/10.1155/2014/ 378981 [17]}

A numerical procedure consisting of a simplified physical model and a numerical method with the aim of optimizing the performance parameters of dye-sensitized solar cells (DSSCs) are proposed [18, 19].

(i) It is calculated the real rate of absorbed photons (in the dye spectral range) $G \operatorname{real}(x)$ by introducing a factor $\beta<1$ in order to simplify the light absorption and reflection on TCO electrode.

(ii) The proposed numerical procedure is applied on a classical DSSC based on Ruthenium dye in order to validate it [20].

(iii) There are simulated the I-V characteristics and calculated the main parameters: short-circuit current density $J_{\mathrm{sc}}$, open circuit voltage $V_{\mathrm{oc}}$, fill factor FF, and power conversion efficiency $\eta$.

(iv) There are analysed the influence of the nature of semiconductor $\left(\mathrm{TiO}_{2}\right)$ and the influence of different technological parameters on the performance parameters of DSSCs. 
(v) The proposed numerical procedure is suitable for developing a numerical simulation platform for improving the DSSCs performance by choosing the optimal parameters.

\subsubsection{Optimization of black dye-sensitized solar cells by numerical simulation - Mihai Razvan Mitroi and Laurentiu Fara, Journal of Renewable Sustainable Energy 5, 041818 (2013); http://dx.doi.org/10.1063/1.4817719 [21]}

The numerical simulation of the physical parameters for dye-sensitized solar cells with black dyes was considered based on a new optimizing procedure.

(i) It is used a new procedure for optimizing established by Mitroi et al., which describes DSSC operation and focuses on the influence of oxide or semiconductor parameters, namely the thickness and lifetime, on the solar cell characteristics.

(ii) This model is successfully applied to a DSSC based on nanoporous TiO2 layer coated with a monolayer of black dyes. The I-V characteristic of DSSC was numerically simulated, and its main parameters, $\mathrm{J}_{\mathrm{sc}}$ (shortcircuit current density), $\mathrm{V}_{\mathrm{oc}}$ (open circuit voltage), FF (fill factor), and $\eta$ (efficiency) were determined [22].

(iii) Based on the influence of the $\mathrm{TiO}_{2}$ film thickness, d, over the cell parameters, the optimal film thickness $\mathrm{d}=10 \mu \mathrm{m}$ was determined. For this optimal film thickness, $\mathbf{J}_{\mathrm{sc}}$ and $\eta$ reach their maximum values of 19.699 $\mathrm{mA} / \mathrm{cm}^{2}$ and $14.289 \%$, respectively [23]. A suitable film thickness of $10-50 \mu \mathrm{m}$ for $\mathrm{TiO}_{2}$ layer was found in a way in which both $\mathrm{J}_{\mathrm{sc}}$ and $\eta$ are decreasing with the increasing of thickness [24, 25]. It was established that $\mathrm{J}_{\mathrm{sc}}$ and $\eta$ significantly decrease when the lifetime $\tau$ increases up to $100 \mathrm{~ms}$. The simulation results can be used to optimize the manufacturing process of black dyes solar cells.

\subsubsection{New materials for hybrid dye-sensitized solar cells - Aurel Diacon, Laurentiu Fara, Corneliu Cincu, Mihai Razvan Mitroi, Catalin Zaharia, Edina Rusen, Cristian Boscornea, Constantin Rosu, Dragos Comaneci, Optical Materials, Vol. 32, pp. 1583-1586, Oct. 2010, DOI:10.1016/j.optmat.2010.06.003 [26]}

This article deals with the synthesis and characterization of new phtalocyanine based chromophores and new electrolyte for the fabrication of hybrid 
dye-sensitized solar cells (hybrid DSSCs). This type of photovoltaic cells is not presented so far in the literature.

(i) There were obtained and characterized by SEM and XRD analysis porous nanostructurated films of $\mathrm{TiO}_{2}$. These films were used for the depositions by self-assembly on the surface of photochemical resistant dyes who serve as sensitizers for the solar cell. The fluorescence characteristics of the dyes were investigated [27].

(ii) In order to obtain a new design for a hybrid dye-sensitized solar cell, a polymer with enhanced mobility based on quaternary salts was synthesized and used to replace the classic electrolyte system; this kind of polymer has not been mentioned in the literature so far for the obtaining of DSSC.

(iii) Considering the solar cell as a diode, it is known that the series resistance of the diode junction depends on the technological process. This fact is very important during simulated solar irradiation when the photocurrent of the solar cell is high. Its change leads to the variation of the cell parameters $\mathrm{V}_{\mathrm{oc}}$ and $\mathrm{J}_{\mathrm{sc}}$, which explains the time degradation of the solar cells [28].

(iv) $\mathrm{PbS}$ and $\mathrm{CdS}$ nanoparticles were chemically generated in the presence of the polymer solution. The best results were obtained in the case of $\mathrm{CdS}$ where the dimension of the generated nanoparticle was $10 \mathrm{~nm}$. The performance of quantum dots based photovoltaics is dramatically influenced by dimension, respectively dispersion of these nanoparticles.

\subsection{Polymer Solar Cells}

\subsubsection{Numerical analysis of $\mathrm{J}-\mathrm{V}$ characteristics of a polymer solar cell - Mihai Razvan Mitroi, Vladimir lancu, Laurentiu Fara, Magdalena Lidia Ciurea, Progress in Photovoltaics, Vol. 19, Issue 3, pp. 301-306, May 2011, DOI: 10.1002/pip.1026 [29]}

A numerical method to determine the cell parameters from the analysis of the $I-V$ characteristics of a polymer solar cell is proposed. This method uses the equations given by the diode model, experimental data from the literature, and an adequate fitting procedure with seven fit parameters [30, 31].

(i) The behaviour of a polymer solar cell was discussed by applying a numerical analysis method to experimental data from literature. 
The Rosenbrock quasi-Newton estimation method for the fitting of the data and a dedicated program were used.

(ii) This original procedure allows to determine all the main parameters of the cell: the saturation current density $\mathrm{J}_{\mathrm{S}}$, the series and derivation (parallel) linear resistances $R_{s}$ and $R_{p}$, the idealist factor $g$, the pair generation rate $\mathrm{G}$, the built-in voltage $\mathrm{V}_{\mathrm{bi}}$, the short-circuit current density $\mathrm{J}_{\mathrm{sc}}$, the open-circuit voltage $\mathrm{V}_{\mathrm{oc}}$, the fill factor FF and the conversion efficiency $\eta$.

(iii) These parameters describe both the physical nature of the active layer and the technological characteristics of the cell. The used procedure also enables to determine the influence of the different parameters on the total current density, the fill factor and the most important, the power conversion efficiency [32]. The procedure is complete and of general application in the field of polymer solar cells.

\subsection{Thin Film Solar Cells}

\subsubsection{Optical field characterization of simulated multilayers for advanced inorganic thin film solar cells - Constantin Dumitru, Vlad-Florin Muscurel, Laurentiu Fara and Paul Sterian, Proceedings WREC 2015, Journal of Renewable Energy and Environmental Sustainability, 1, 3, 2016 (to be published) [33]}

An analysis of optical processes (reflectance and absorption) was conducted for advanced thin film solar cells based on cadmium and metal oxides, in order to evaluate and improve the optical performance [34].

(i) This is considered as an emerging technology in multilayer stacks for optical performance evaluation. Using a comparative analysis with metal oxide heterojunction, by the optical field characterization, it has been demonstrated that the metal oxide and silicon tandem design could be viable.

(ii) Optical modelling was performed on cadmium thin film solar cells as well as metal oxides based on silicon heterojunction tandem devices for their characterization.

(iii) The assessment has been made for the light interference and absorption spectra, as a basis, with the generation rate and E-field intensity derived as means of optimization.

(iv) The simulation methodology could be used for optical performance optimization, by comparison with experimental data $[35,36]$. 


\subsection{Forecasting Photovoltaic System Output}

\subsubsection{New results in forecasting of photovoltaic systems output based on solar radiation forecasting - Alexandru Diaconu, Laurentiu Fara, Blanka Bartok, Andrei Galbeaza Moraru, Cristian Oprea, Paul Sterian, Journal of Renewable and Sustainable Energy 08/2013; 5(4), http://dx.doi.org/10.1063/1.4819301 [37]}

The approach on solar radiation forecast used in this paper is based on two methods: autoregressive integrated moving average (ARIMA) and artificial neural network (ANN) [38, 39].

(i) The daily solar irradiation variability has been analysed and four synoptic situations were defined to include the influence of cloudiness changes. Decadal variations of global solar radiation were also considered for long term forecast. The results were obtained using a database from Bucharest/Afumati Meteorological Station.

(ii) A more accurate forecasting model for a PV system's power output based on solar radiation forecasting results was developed [40, 41]. By using complete datasets and including meteorological parameters such as cloudiness, relative humidity, air temperature, atmospheric pressure, and sunshine duration, as input for the used model, the forecasting errors were minimized and a more accurate forecast of the power output for the analysed demo PV system has been obtained.

\subsubsection{Forecasting platform of PV systems based on statistical approach - Alexandru Diaconu, Laurentiu Fara, Blanka Bartok, Paul Sterian, Silvian Fara, Proceedings WREC 2015, Journal of Renewable Energy and Environmental Sustainability, 1, 3, 2016 (to be published) [42]}

This paper analyses the daily irradiation variability, as well as other meteorological parameters which could affect the PV power output.

(i) The statistical approaches used in order to forecast the surface solar radiation are the Autoregressive Integrated Moving Average (ARIMA) and the Artificial Neural Network (ANN) models [43, 44], on available datasets from ANM (National Administration of Meteorology, Baneasa Meteorological Station) and also from the investigated PV park's weather stations. 
(ii) To have a better understanding of the effect of different surface solar radiation forecasting methods on PV output, the PV park's operating parameters have also been analysed. The tests had been done in a certain period of time to see the differences in PV power output using various surface solar radiation forecasts; thus it have been determined a correct balance of how this forecasts will affect the final output. The power output was generated taking into consideration the best estimated results compared with the power generated onsite.

\subsubsection{BIPV (Building Integrated Photovoltaic) systems in Romania. Monitoring, modelling and experimental validation - Alexandru Diaconu, Laurentiu Fara, Paul Sterian, Silvian Fara, Andreea Bobei, Andrei Galbeaza Moraru, Journal of Optoelectronics and Advanced Materials, Vol. 15, No. 1-2, January-February 2013, pp. 125-130 [45]}

The study is dedicated to the performance analysis of a BIPV (Building Integrated Photovoltaic) system developed in Romania and mounted on the building of the Polytechnic University of Bucharest (PUB) [46]; such systems highly depend on the fluctuation of incoming solar radiation reaching the PV system's surface.

(i) The estimation of the energy production of the BIPV system, on a short term period (two days), is considered as the main objective of the article.

(ii) Short-term solar irradiation forecasts are elaborated in two ways, based on the meteorological experimental datasets. First, forecasting tests are run using Autoregressive Integrated Moving Average (ARIMA) models. Second, artificial neural network (ANN) techniques are also evaluated in order to enhance the forecasts of solar irradiation.

(iii) The validation of the obtained results by real measurements determines the error range of the forecasted values quantified by the root-meansquare error (RMSE), as well as an estimation of energy production between forecasted and measured values.

\section{Modelling and Simulation for Advanced Solar Cells - Global Vision}

The book "Advanced Solar Cell Materials, Technology, Modelling, and Simulation", Laurentiu Fara and Masafumi Yamaguchi (editors), published 
by IGI Global(USA), 2013 [1], could be considered as a precursory contribution to the MultiscaleSolar COST project (2015-2019) and a trial to introduce a global vision in modelling and simulation of advanced solar cells.

Four generations of solar cells have been developed until now. The third and fourth generations of solar cells are potentially able to overcome the Shockley-Queisser conversion efficiency of $31 \%$ at l-sun and $41 \%$ under concentration for single bandgap solar cells [47].

Limiting efficiencies are expected to be $28.9 \%, 23.5 \%, 23.5 \%, 17.5 \%$, and $16 \%$ for crystalline $\mathrm{Si}$, thin-film Si, CIGS as well as CdTe, dye-sensitized and organic solar cells, respectively. On the other hands, because $41.6 \%$ efficiency has been realized with concentrator $\mathrm{InGaP} / \mathrm{InGaAs} / \mathrm{Ge} 3$-junction solar cells, concentrator 4-junction or 5-junction solar cells have great potential for realizing super high-efficiency of over $50 \%$. At the same time, in order to to overcome conversion efficiency limitations, developing new types of solar cells based on new materials and new concepts is very important. Thirdgeneration solar cells include both multi-layered/multi-junction solar cells and intermediate bands, hot-carrier solar cells. Realistic conversion efficiencies obtained for solar cells by using the above concepts could be less than $55 \%$ by considering possible efficiency based on the realistic multi-junction (tandem) concept. However, further R\&D for new materials and new concepts is necessary to challenge to overcome the Shockley-Queisser limit.

The book is dedicated especially to the third generation of solar cells [48] and it is structured on five sections, namely:

- Section 1: Basic Topics: Chapter 1, "New Trends in Solar Cells," and Chapter 2, "Physical Limitations of Photovoltaic Conversion".

- Section 2: Quantum Well Solar Cells: Chapter 3, "Quantum Well Solar Cells: Physics, Materials, and Technology," Chapter 4, "Quantum Confinement Modelling and Simulation for Quantum Well Solar Cells," Chapter 5, "Analytical Models of Bulk and Quantum Well Solar Cells and Relevance of the Radiative Limit".

- Section 3: Hybrid and Polymer Solar Cells: Chapter 6, "Hybrid Solar Cells: Materials and Technology," Chapter 7, "Polymer Solar Cells," Chapter 8, "Organic Solar Cells: Modelling and Simulation".

- Section 4: High Efficiency Solar Cells: Chapter 9, "Super High Efficiency Multi-Junction Solar Cells and Concentrator Solar Cells," Chapter 10, "Quantum Dot Solar Cells," Chapter 11, "Intermediate Band Solar Cells: Modelling and Simulation," Chapter 12, "Phononic Engineering for the Hot Carrier Solar Cells". 
- Section 5: Luminescent Solar Concentrators: Prospects and Strategies for Advanced Solar Cells: Chapter 13, "The Luminescent Solar Concentrator: Advances, Optimization, and Outlook, Chapter 14, "Prospects and Strategy of Development for Advanced Solar Cells".

This special book looks for to present the main results obtained by international research regarding materials, technology, modelling, and simulation of different types of advanced solar cells. There are simulated the essential mechanisms using fundamental models of advanced solar cells, in order to understand better these mechanisms and to evaluate new methodologies. New materials, concepts and devices are considered. The book stressed on innovative approaches in photovoltaics using quantum confinement, as well as light and thermal management.

In order to overcome clean energy supply problems due to possible nuclear power plant crises, further deployment of PV power generating systems as well as further development in science and technology of PV are very important. Very large scale installation of PV power generating systems and further improvements in conversion efficiencies and reliability and lowering the cost of solar cells and modules are necessary.

\section{World PV Market Development}

\subsection{World Market Performances for 2014}

In the world, $40 \mathrm{GW}$ of PV systems were installed in 2014, compared with 38.4 GW in 2013 and $30 \mathrm{GW}$ in 2012, setting a new record for the solar PV sector; PV remains, after hydro and wind power, the third most important renewable energy source in terms of globally installed capacity $[49,50]$. This level of installations has been achieved due to:

- the growth of Asian and American markets;

- the emergence of new markets.

- China officially installed 10.6 GW of PV in 2014, with strong political support and feed-in tariffs based policies.

- Japan installed 9.7 GW of PV in 2014, based on feed-in tariffs policies and self-consumption measures.

- US installed 6.5 GW in 2014; California contributed to more than $50 \%$ of all US solar PV installations in 2014.

- UK installed 2.4 GW in 2014, based on a combination of incentives.

- The PV market in Germany decreased to 1.9 GW installed in 2014 with reduced incentives. 
- France installed more than 900 MW in 2014.

- Korea, Australia and South Africa installed each roughly $900 \mathrm{MW}$ in 2014.

- Canada, Taiwan, Thailand, Netherlands and Chile installed each close to $500 \mathrm{MW}$ in 2014.

All these evaluations mark a progress in all regions of the world.

\subsection{The Main PV World Market Features in 2014}

- Increasing competitiveness

PV markets in Europe and around the world continued to make rapid progress toward competitiveness in the electricity sector in 2014. Strong PV technology price decreases and electricity prices on the rise have helped drive momentum toward "dynamic grid parity" - when the savings in electricity cost and/or the revenues generated by selling PV electricity on the market are equal to or higher than the long-term cost of installing and financing a PV system.

- The market in Europe slowed down in 2013 and this trend continued in 2014.

However Europe is still the predominant player, with more than $88 \mathrm{GW}$ installed at the end of 2014. The 2014 solar PV markets showed a perfect balance between utility scale installations and distributed ones.

- $P V$ - an important factor in the electricity mix

For the fourth year in a row, PV in 2014 was amongst the two most installed sources of electricity in the European Union. While wind energy exceeded PV in 2013 by some hundreds of MW, these two sources of electricity are the clear leaders of new generation sources of installations. PV now covers $3 \%$ of the electricity demand and $6 \%$ of the peak electricity demand in Europe. As the share of PV in the electricity mix increases, grid and market integration challenges are becoming more and more important for the future development of PV.

\section{High Opportunities for PV Development}

The main high opportunities for PV development are put in evidence by the international research [51] and could be considered as follows:

- Reliable solar radiation database to make smart forecasted PV output

- PV performance modelling - spectral corrections 
- Bonding and sealing technology-new adhesive solutions for PV modules

- Development of PV ribbon products

- Progressive integration of PV systems in electricity market to maintain the grid stability

\subsection{Reliable Solar Radiation Database to Make Smart Forecasted PV Output}

Sandia National Laboratories is facilitating a collaborative group of PV professionals (PV Performance Modelling Collaborative or PVPMC) [51]. This group is interested in improving the accuracy and technical rigor of PV performance models and analyses. Solar radiation databases and important weather data that could influence the PV forecasted output could be found in some of the most important platforms, such as:

- EUMETSAT - is an intergovernmental organisation and was founded in 1986. Our purpose is to supply weather and climate-related satellite data, images and products - 24 hours a day, 365 days a year - to the National Meteorological Services of our Member and Cooperating States in Europe, and other users worldwide.

- The SODA service - is a broker to a list of services and web services. It offers a one-stop access to a large set of information relating to solar radiation and its use. This is an Intelligent System (SoDa-IS) that builds links to other resources that are located in various countries [52].

- ECMWF - The European Centre for Medium-Range Weather Forecasts is an independent intergovernmental organization supported by 34 states. ECMWF is both a research institute and a 24/7 operational service, producing and disseminating numerical weather predictions to its Member States. This data is fully available to the national meteorological services in the Member States.

\subsection{Spectral Corrections for PV Performance Modelling}

Solar spectral irradiance variation has a demonstrated effect on photovoltaic device performance. The significance of the effect with respect to energy yield has been shown to be technology-specific, through device spectral response, and site-specific, since spectral variation depends on atmospheric path length and cloud cover.

The performance of a PV module is rated at Standard Reporting Conditions (SRC). However, PV modules perform under a variety of conditions where 
the spectral distribution varies from the ASTM spectrum. Spectral distribution is primarily influenced by the path length through the atmosphere and the amounts of atmospheric water vapour and aerosols. These factors cause diurnal, seasonal, and geographic variations in spectral distribution that can increase or decrease $\mathrm{I}_{\mathrm{sc}}$. Variations in spectral distribution are more likely to impact the performance of $\mathrm{PV}$ modules that respond to a narrower wavelength range of solar radiation, such as amorphous silicon, than those that respond to a wider wavelength range of solar radiation, such as crystalline silicon [53].

Various approaches for correcting variations in spectral distribution have been completed. Some of the most important are (1) Empirical relationships based on air mass or path length through the atmosphere, and (2) Use of spectral irradiance models with PV module spectral response data [54].

\subsection{Bonding and Sealing Technology - New Adhesive Solutions for PV Modules}

Because the market conditions put pressure on the entire photovoltaic installation, efforts are being made for developing new processes for optimization and installation to reduce the costs. This also leads to new materials and methods that have to be implemented into production and installation.

There are a number of features that new adhesive and sealants are currently researched to be developed, leading to lower production costs and higher efficiency. For example, Sika Corporation is adding value to their products by implementing the following benefits to their products [55].

Table 2 Features and benefits in using new bonding and sealing technology

\begin{tabular}{|c|c|c|}
\hline & Adhesive Features & $\begin{array}{c}\text { Benefits for the } \\
\text { Photovoltaic System }\end{array}$ \\
\hline Substrate-friendly & $\begin{array}{l}\text { - Absorbs shocks and reduces } \\
\text { vibrations }\end{array}$ & $\begin{array}{l}\text { Eliminated stress peaks for } \\
\text { reduced glass breakage }\end{array}$ \\
\hline joining method & $\begin{array}{l}\text { - Optimal load distribution } \\
\text { across the surface } \\
\text { - Accomodates the different } \\
\text { thermal expansion coefficients } \\
\text { of the construction and glass } \\
\text { - Compensates for } \\
\text { manufacturing tolerances } \\
\text { - Bonding of finished materials } \\
\text { e.g., aluminum - glass) }\end{array}$ & $\begin{array}{l}\text { - Dimished formation of micro } \\
\text { cracks in cells } \\
\text { - Higher yield over service life } \\
\text { - Withstands all climatic zones } \\
\text { - Simplified automation and } \\
\text { fewer upstream process steps } \\
\text { - No damage to corrosion } \\
\text { protection as a result of } \\
\text { drilling or screwing }\end{array}$ \\
\hline
\end{tabular}


Table 2 Continued

\begin{tabular}{|c|c|c|}
\hline & Adhesive Features & $\begin{array}{c}\text { Benefits for the } \\
\text { Photovoltaic System }\end{array}$ \\
\hline Scope for design & $\begin{array}{l}\text { Concealed bonding makes for } \\
\text { smooth, barrier-free surfaces }\end{array}$ & $\begin{array}{l}\text { - Elimination of frames or } \\
\text { mechanical fixing } \\
\text { - Increased self cleaning of } \\
\text { modules for higher yield } \\
\text { - Appeal for BIPV solutions } \\
\text { - Lower transport costs } \\
\text { - Simplified installation } \\
\text { - Wider range of applications }\end{array}$ \\
\hline $\begin{array}{l}\text { Dynamic load } \\
\text { capacity }\end{array}$ & $\begin{array}{l}\text { - Wind and other loads can he } \\
\text { transferred evenly into the sub } \\
\text { construction }\end{array}$ & $\begin{array}{l}\text { - Less glass breakage and fewer } \\
\text { micro-cell cracks } \\
\text { - Improved long-term durability } \\
\text { - Reduced operating costs } \\
\text { - Less maintenance work }\end{array}$ \\
\hline $\begin{array}{l}\text { Product } \\
\text { performance }\end{array}$ & $\begin{array}{l}\text { - Different curing speeds and } \\
\text { technologies available } \\
\text { - Widely approved (e.g., IEC } \\
\text { 61215/61646/61730, EOTA } \\
\text { ETAG 002, UL 94/764) }\end{array}$ & $\begin{array}{l}\text { - Curing speed fits the process } \\
\text { to eliminate curing zones } \\
\text { - Moisture independent curing } \\
\text { possible } \\
\text { - Secured system durability and } \\
\text { performance }\end{array}$ \\
\hline
\end{tabular}

Table 3 Key system benefits

$\begin{array}{ll}\begin{array}{l}\text { Reduced costs in production and } \\ \text { installation }\end{array} & \text { Increased durability and performance } \\ \text { - Savings in costs of up to 15\% compared } & \text { - Reduced glass breakage through } \\ \text { to common framing and installation } & \text { elimination of stress peaks } \\ \text { systems } & \text { - Minimized micro cracks on cells due } \\ \text { - Reduced installation time on-site of up } & \text { to stress distribution simply higheryield } \\ \text { to } 40 \% & \text { over service life } \\ \text { - Savings in backrail material of up } & \text { - Elimination of raised edges from frames } \\ \text { to } 15 \% \text { compared to tape solutions } & \text { that trap dirt, snow or water which harm } \\ \text { - Value added through mounting } & \text { the laminate and reduce the power output } \\ \text { integration, new designs for BIPV } & \text { - Structurally bondedwith an adhesive } \\ \text { and architectural appeal } & \text { technology which meets stringent } \\ \text { - Elimination of electrical grounding } & \text { durability requirements } \\ \text { - Minimized material handling compared } & \text { - Simplified tolerance compensation } \\ \text { to clamping } & \text { of bonded components }\end{array}$

The company is also introducing a different way to mount the photovoltaic modules by moving from frames and mechanical mounting, to a bonded frameless mounting solution that has the following advantages [55]. 


\subsection{Development of PV Ribbon Products}

One of the most important components of the PV system design is represented by the PV ribbon products. Efforts are made for producing more efficient solar tabbing and bus wire to help obtain the highest efficiency possible. The latest technology developed by Ulbrich Solar Technologies, consists in a innovative grooved solar cell tabbing ribbon, that increases the efficiency of a solar module by reflecting light back onto the surface of the cell. This grooved ribbon replaces the traditional wire that connects solar cells together. Eighty percent of the photocurrent from light that strikes the ribbon is recovered-far better than the 5\% recovered by standard interconnects wire. The recaptured light creates up to a $2 \%$ module efficiency gain. In addition to tinned copper wire, Ulbrich also manufactures silver plated copper, aluminium alloys, hybrid alloys and metal substrate materials [56].

\subsection{Progressive Integration of PV Systems in Electricity Market to Maintain the Grid Stability}

The subject of grid integration coupled with renewable power generation is playing an increasingly important role. The optimum integration of the decentralized and variable power generation capacity of PV systems into the existing distribution grid (designed for unidirectional flows of power) is as crucial as it is pressing for that very reason.

There are already progressive approaches for the optimum grid integration of renewable power generation capacity that go beyond both directives: Comprehensive energy management at the household level, the incorporation of solar radiation forecasts, and the use of local storage systems are paving the way to the intelligent grid, the "smart grid". SMA is also committed to this field? with the development of the innovative Sunny Home Manager, the collaboration with PV forecast services, or the advancement of the proven Sunny Backup system for a grid-connected storage solution [57].

\section{Relevant European PV Market in 2014}

The relevant market combines the product market and the geographic market. Photovoltaics had showed an aggressive grow, however, political support differs from one country to another. Reasons could be some of the following:

- The overall decline in Europe's PV market in 2013 hides various realities at national level 
- The development until 2014 was accompanied by a progressive evolution in market dynamics, with PV in 2014 becoming increasingly self-sustainable in several market segments and countries.

- The competitiveness of PV installations not only depends on the ability of PV to reduce electricity bills, but also to sell excess electricity on the markets. Several countries took retrospective measures that reduced the revenues of existing PV plants in the last few years (Spain, Czech Republic, Bulgaria and Greece), damaging the attractiveness of PV as a long-term investment.

- For the second time in the last years, the installations in Germany went down to $3.3 \mathrm{GW}$. Germany saw four consecutive years with a roughly stable 7.4-7.6 GW of connections, leading to a total installed capacity in the country of a record $35.7 \mathrm{GW}$. However, regulatory changes pushed the market down.

- With close to $90 \mathrm{GW}$ of PV capacity in European countries, the 2020 targets defined in 2009 have been reached in 2014 by 9 countries [58], 6 years ahead of the target date.

The evolution of European PV installed capacity in the period 2000-2014 is presented in Figure 5 [49]. Distribution per country of annual installed capacity, cumulative installed, as well as political support for PV, is emphasized in Table 4 [50].

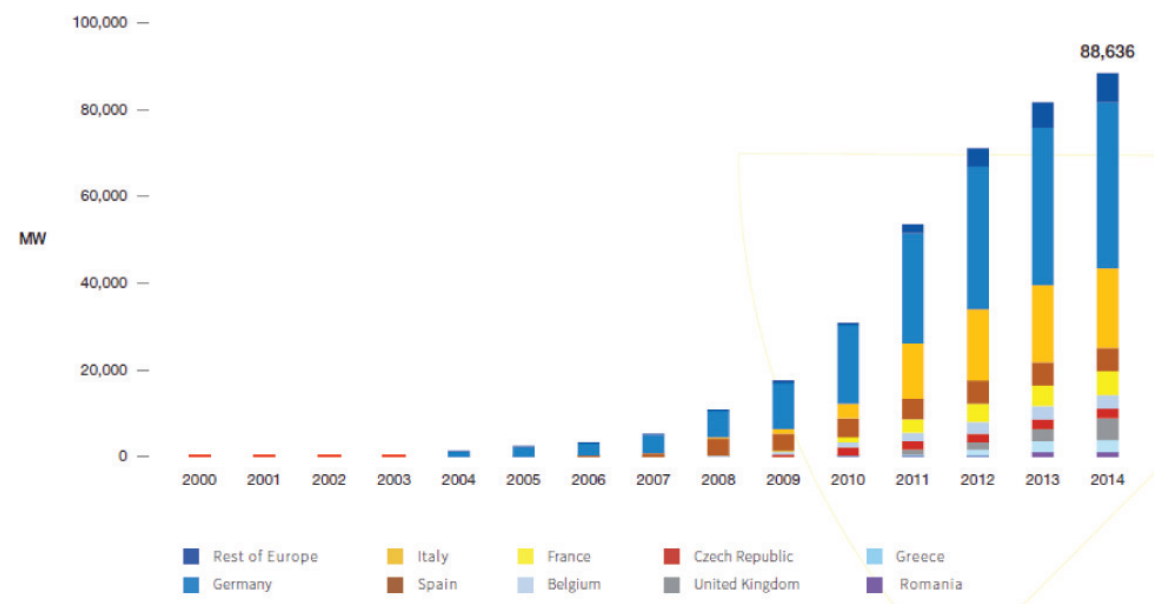

Figure 5 Evolution of European solar PV cumulative installed capacity 2000-2014 [49]. 
Table 4 European solar PV market and prospects [50]

\begin{tabular}{|c|c|c|}
\hline Country & $\begin{array}{c}\text { Cumulative } \\
\text { Installed } \\
\text { Capacity } \\
2014 \text { (MW DC) }\end{array}$ & $\begin{array}{l}\text { Political Support } \\
\text { Prospects }\end{array}$ \\
\hline Austria & 767 & political support works well \\
\hline Belgium & 3.104 & political support works partially OK \\
\hline Bulgaria & 1.022 & drastic measures regarding political support \\
\hline Croatia & 33 & political support works partially OK \\
\hline Cyprus & 65 & political support works partially OK \\
\hline Czech Republic & 2.134 & drastic measures regarding political support \\
\hline Denmark & 608 & political support works well \\
\hline Estonia & 0.2 & political support works partially $\mathrm{OK}$ \\
\hline Finland & 11.2 & political support works well \\
\hline France & 5.632 & political support works partially OK \\
\hline Germany & 38.235 & political support works partially OK \\
\hline Greece & 2.596 & political support works partially OK \\
\hline Hungary & 80 & political support works partially OK \\
\hline Ireland & 1.1 & political support works well \\
\hline Italy & 18.313 & political support works partially OK \\
\hline Latvia & 1.5 & political support works partially OK \\
\hline Lithuania & 68 & political support works partially OK \\
\hline Luxembourg & 110 & political support works well \\
\hline Malta & 23 & political support works partially OK \\
\hline Netherlands & 1.042 & political support works well \\
\hline Poland & 34 & drastic measures regarding political support \\
\hline Portugal & 414 & political support works partially OK \\
\hline Romania & 1.223 & political support works partially OK \\
\hline Slovakia & 524 & political support works partially OK \\
\hline Slovenia & 256 & political support works well \\
\hline Spain & 5.388 & drastic measures regarding political support \\
\hline Sweden & 79 & political support works well \\
\hline Switzerland & 1.046 & political support works well \\
\hline Turkey & 58 & political support works well \\
\hline United Kingdom & 5.230 & political support works well \\
\hline
\end{tabular}

\section{Forecasts of PV in Europe until 2019}

The European market would first grow between $7 \mathrm{GW}$ (low scenario) and 11 GW (high scenario) in 2015, before increasing again at a slower pace with installations ranging between $6 \mathrm{GW}$ in 2015 and $17 \mathrm{GW}$ (expected) in 2019 (see Figure 6) [50]. 


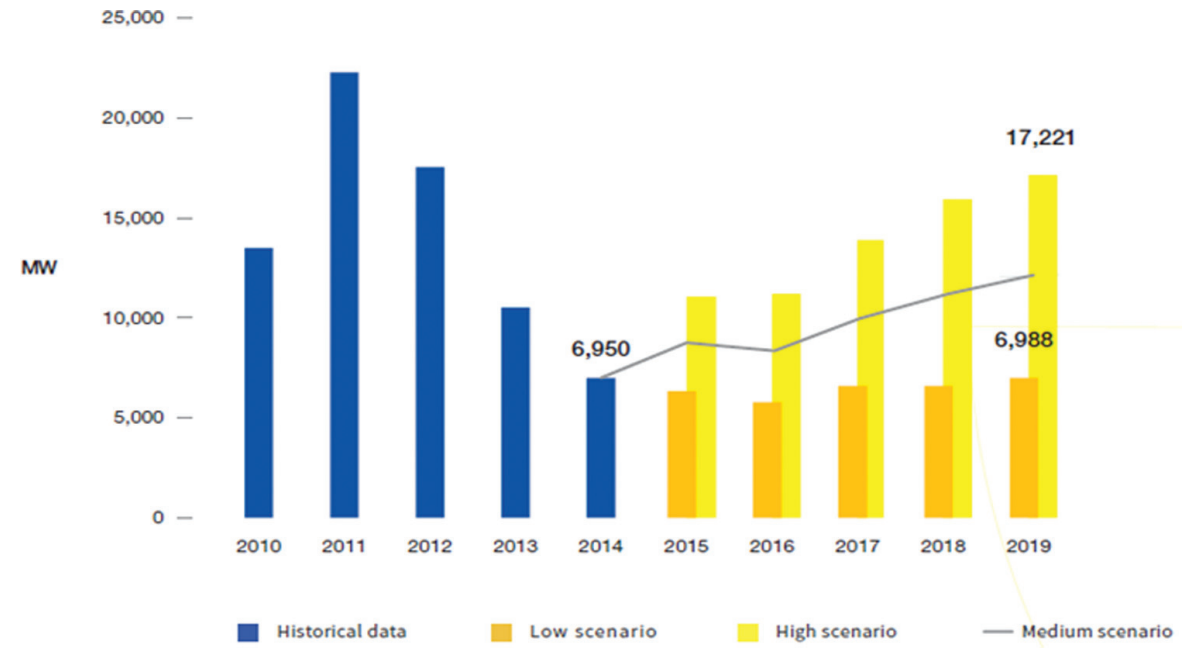

Figure 6 European annual solar PV market scenarios until 2019 [50].

- According to the high scenario, the European market could reach a total installed capacity of $158 \mathrm{GW}$ by 2019 , an almost $80 \%$ market increase compared to today.

- In the low scenario, the total installed capacity would be above $120 \mathrm{GW}$ by 2019.

- In the medium scenario, the total installed capacity would be roughly 140 GW by 2019.

\section{Conclusions and Prospects}

After many years of growth and innovation, the PV industry is again going through a challenging period, with shifting market dynamics and a different geographical focus. In Europe, changing political support has created a climate of uncertainty that will hamper the re-development of the PV market. But outside Europe, the potential for growth remains intact and the various projects appearing in dozens of countries could transform into real market take-off. Going forward, the key issues that will play a role in determining how market evolution takes place include:

- Policy: The PV market remains in most countries a policy-driven market, as shown by the significant market decrease in countries where harmful and retrospective political measures have been taken. However, with the 
right decisions creating smart and sustainable support schemes for PV, markets can continue to grow in a number of countries.

- Competitiveness: In some countries in some segments, PV is already competitive with other power sources in terms of levelled cost of electricity. In other countries, it is rapidly moving towards cost-competitiveness. Grid and market integration challenges should be addressed without delay in order not to further hamper future PV development.

- Industry consolidation: With a global PV modules overcapacity that is less acute than one or two years ago, prices have stabilised in 2014 and the return to profitability should allow companies to invest again. This could in return lead to prices of new technology declining in the coming years and new markets opening for PV. The enormous potential of solar PV and its benefits for society are very obvious. PV is becoming a mainstream player within the power system. Under all scenarios, PV will continue to increase its share of the energy mix in Europe and around the world, increasingly delivering clean, safe, affordable and decentralised electricity to people.

\section{References}

[1] L. Fara, M. Yamaguchi, 'Advanced Solar Cell Materials, Technology, Modelling, and Simulation', IGI Global Publishing House, USA, 2013, doi: 10.4018/978-1-4666-1927-2.

[2] WBGU, 'World in transition - Towards sustainable energy systems', London, UK: Earthsan, 2003.

[3] M. A. Green, K. Emery, Y. Hishikawa, W. Warta, 'Solar cell efficiency tables. Progress in Photovoltaics: Research and Applications', 19, 84, 2011.

[4] http://costing.irena.org/charts/solar-photovoltaic.aspx

[5] Bloomberg New Energy Finance \& pv.energytrend.com, 2015.

[6] S. Fara, P. Sterian, L. Fara, M. Iancu, A. Sterian, 'New Results in Optical Modelling of Quantum Well Solar Cells', International Journal of Photoenergy, Volume 2012, doi:10.1155/2012/810801.

[7] K. W. J. Barnham, G. Duggan, 'Ideal theory of quantum solar cells', Journal of Applied Physics, 67, 3490, 1990, doi:10.1063/1.345339.

[8] M. Paulescu, P. Gavrila, E. Tulcan-Paulescu, 'Optical and electrical modelling of multiple quantum well solar cells', Scientific Bulletin of the University "Politehnica" of Timisoara, vol. 53, no. 66, pp. 114-121, 2007. 
[9] R. Dahal, B. Pantha, J. Li, J. Y. Lin, and H. X. Jiang, 'InGaN/GaN multiple quantum well solar cells with long operating wavelengths', Applied Physics Letters, vol. 94, no. 6, 2009.

[10] V. Iancu, L. Fara, and R. M. Mitroi, 'Quantum confinement modeling and simulation for quantum well solar cells', Annals of the Academy of Romanian Scientists, vol. 1, no. 1, pp. 35-46, 2009.

[11] M. S. A. Abdel-Mottaleb, J. A. Byrne, and D. Chakarov, 'Nanotechnology and solar energy', International Journal of Photoenergy, vol. 2011, 2011.

[12] K. W. J. Barnham, I. Ballard, J. P. Connolly et al., 'Quantum well solar cells' Physica E, vol. 14, no. 1-2, pp. 27-36, 2002.

[13] A. Badea, F. Dragan, L. Fara, P. Sterian, 'Quantum mechanical effects analysis of nanostructured solar cell model', Renew. Energy Environ. Sustain. 1, 3, 2016, doi: 10.1051/rees/2016003.

[14] S. M. Hubbard et. al., 'Effect of Strain Compensation on Quantum Dot Enhanced GaAs', Solar Cells Appl. Phys. Lett. 92, 123512, 2008.

[15] S. M. Sze, K. Ng, 'Physics of semiconductor devices, 3rd edition', John Wiley \& Sons, Hoboken, p. 58, 2007.

[16] S. M. Hubbard et. al., 'Growth and characterization of inas quantum dot enhanced photovoltaic devices', Mater. Res. Soc. Symp. Proc. 1017E, DD13, 2007.

[17] M. R. Mitroi, L. Fara, M. L. Ciurea, 'Numerical Procedure for Optimizing Dye-Sensitized Solar Cells', Journal of Nanomaterials, Volume 2014, 6 pp, 2014, doi: 10.1155/2014/378981.

[18] H. S. Jung and J. K. Lee, 'Dye sensitized solar cells for economically viable photovoltaic systems', The Journal of Physical Chemistry Letters, vol. 4, no. 10, pp. 1682-1693, 2013.

[19] L. Andrade, J. Sousa, H. Aguilar Ribeiro, and A. Mendes, 'Phenomenological modeling of dye-sensitized solar cells under transient conditions', Solar Energy, vol. 85, no. 5, pp. 781-793, 2011.

[20] F. Gao, Y. Wang et al., 'Enhance the optical absorptivity of nanocrystalline $\mathrm{TiO}_{2}$ film with high molar extinction coefficient ruthenium sensitizers for high performance dye-sensitized solar cells', Journal of the American Chemical Society, vol. 130, no. 32, pp. 10720-10728, 2008.

[21] M.R. Mitroi, L. Fara, 'Optimization of black dye-sensitized solar cells by numerical simulation', Journal of Renewable Sustainable Energy 5, 041818 2013, doi: 10.1063/1.4817719, 2013.

[22] M. Giannouli, G. Syrrokostas, P. Yianoulis, 'Effects of using multicomponent electrolytes on the stability and properties of solar cells 
sensitized with simple organic dyes', Prog. Photovoltaics 18, 128-136, 2010.

[23] A. B. F. Martinson, M. S. Goes, F. F. Santiago, J. Bisquert, M. J. Pellin, and J. T. Hupp, 'Electron transport in dye-sensitized solar cells based on $\mathrm{ZnO}$ nanotubes: Evidence for highly efficient charge collection and exceptionally rapid dynamics', J. Phys. Chem. A 113, pp. 4015-4021, 2009.

[24] G. Calogero, J. H. Yum, A. Sinopoli, G. Di Marco, M. Gratzel, M. K. Nazeeruddin, 'Anthocyanins and betalains as light-harvesting pigments for dye-sensitized solar cells', J. Sol. Energy 86, pp. 1563-1575, 2012.

[25] T. Bessho, S. M. Zakeeruddin, C. Y. Yeh, E. W. G. Diau, M. Gratzel, 'Highly efficient mesoscopic dye-sensitized solar cells based on donoracceptor-substituted porphyrins', Angew. Chem. 122, pp. 6796-6799, 2010.

[26] A. Diacon, L. Fara, C. Cincu, M. R. Mitroi, C. Zaharia, E. Rusen, C. Boscornea, C. Rosu, D. Comaneci, 'New materials for hybrid dyesensitized solar cells', Optical Materials, Vol. 32, pp. 1583-1586, Oct. 2010, doi: 10.1016/j.optmat.2010.06.003.

[27] Z. Ning, Q. Zhang, W. Wu, H. Tian, J. Organomet. Chem. 694, pp. 27052711, 2009.

[28] L. Fara, M. R. Mitroi, V. Iancu, G. Milescu, G. Noaje, 'Modeling and Numerical Simulation of Nanostructured Solar Cells', Point Publishing House, Bucharest, 2008.

[29] M. R. Mitroi, V. Iancu, L. Fara, M. L. Ciurea, 'Numerical analysis of $\mathrm{J}-\mathrm{V}$ characteristics of a polymer solar cell', Progress in Photovoltaics, Vol. 19, Issue 3, pp. 301-306, May 2011, doi: 10.1002/pip.1026.

[30] S. Gunes, H. Neugebauer, N. S. Sariciftci, 'Conjugated polymer-based organic solar cells', Chemical Reviews, 107, pp. 1324-1338, 2007, doi: $10.1021 / \mathrm{cr} 050149 \mathrm{z}$.

[31] M. Burgelman, J. Verschraegen, S. Degrave, P. Nollet, 'Modeling thinfilm PV devices', Progress in Photovoltaics: Research and Applications, 12, pp.143-153, 2004, doi: 10.1002/pip.524.

[32] M. Scharber et al., 'Design rules for donors in bulk-heterojunction solar cells - towards 10\% energy-conversion efficiency', Advanced Materials 18, pp. 789-794, 2006, doi: 10.1002/adma.200501717.

[33] C. Dumitru, V. F. Muscurel, L. Fara, P. Sterian, 'Optical field characterization of simulated multilayers for advanced inorganic thin film solar cells', Renew. Energy Environ. Sustain. 1, 3, 2016 (to be published). 
[34] T. Minami, Y. Nishi, T. Miyata, 'High-efficiency $\mathrm{Cu}_{2} \mathrm{O}$-based heterojunction solar cells fabricated using a $\mathrm{Ga}_{2} \mathrm{O}_{3}$ thin film as n-type layer', Appl. Phys. Express 6, 044101, 2013.

[35] S. Khosroabadi, S. Keshmiri, S. Marjani, 'Design of a high efficiency $\mathrm{CdS} / \mathrm{CdTe}$ solar cell with optimized step doping, film thickness and carrier lifetime of the absorption layer', J. Eur. Opt. Soc-Rapid, 9, 2014.

[36] S. W. Lee, Y. S. Lee et. al., 'Improved $\mathrm{Cu}_{2} \mathrm{O}$-based solar cells using atomic layer deposition to control the $\mathrm{Cu}$ oxidation state at the $\mathrm{p}-\mathrm{n}$ junction', Adv.Energy Mater., 4, 2014.

[37] L. Fara, B. Bartok. A. G. Moraru, C. Oprea, P. Sterian, A. Diaconu, S. Fara, 'New results in forecasting of photovoltaic systems output based on solar radiation forecasting', Journal of Renewable Sustainable Energy 5, 2013, doi: 10.1063/1.4819301.

[38] J. Ebinnger and W. Vengara, 'Climate Impacts on Energy Systems: Key Issues for Energy Sector Adaptation', The World Bank Press, 2011.

[39] M. A. Behrang, E. Assareh, A. Ghanbarzadeh, A. R. Noghrehabadi, "The potential of different artificial neural network (ANN) techniques in daily global solar radiation modeling based on meteorological data," Sol. Energy 84, pp. 1468-1480, 2010.

[40] B. Bartok, 'Changes in solar energy availability for south-eastern Europe with respect to global warming,' Phys. Chem. Earth 35, pp. 63-69, 2010.

[41] E. Lorenz et. al., 'Benchmarking of different approaches to forecast solar irradiance,' in 24th European Photovoltaic Solar Energy Conference, Hamburg, Germany, pp. 4199-4208, 21-25 September 2009.

[42] A. Diaconu, L. Fara, B. Bartok, P. Sterian, S. Fara, 'Forecasting platform of PV systems based on statistical approach', Renew. Energy Environ. Sustain. 1, 3, 2016 (to be published).

[43] M. A. Behrang et. al., 'The potential of different artificial neural network (ANN) techniques in daily global solar radiation modeling based on meteorological data', Solar Energy 84, pp. 1468-1480, 2010.

[44] C. Paoli, C. Voyant, M. Muselli, M. Nivet, 'Forecasting of preprocessed daily solar radiation time series using neural networks', Solar Energy 84, pp. 2146-2160, 2010.

[45] L. Fara, A. G. Moraru, P. Sterian, A. P. Bobei, A. Diaconu, S. Fara, 'Building Integrated Photovoltaic (BIPV) systems in Romania. Monitoring, modelling and experimental validation', Journal of Optoelectronics and Advanced Materials, Vol. 15, No. 1-2, pp. 125-130, January-February 2013. 
[46] L. Fara, A. M. Dabija, S. Fara, D. Finta, M. Iancu, M. Paulescu, 'Building Integrated Photovoltaics (BIPV) in Romania', Proceedings of International Congress Energy and the Environment 2008, Opatija, Croatia, October 22-24, 2008.

[47] W. Shockley, H. J. Queisser, 'Detailed balance limit of efficiency of p-n junction solar cells' Journal of Applied Physics, 32, 510, 1961, doi:10.1063/1.1736034.

[48] M. Green, 'Third generation photovoltaics: Advanced solar energy conversion' Springer, Berlin, Germany, 2003.

[49] G. Masson, S. Orlandi, M. Rekinger, 'EPIA Global Market Outlook for Photovoltaics, 2014-2018', http://www.cleanenergybusinesscouncil.com /site/resources/files/reports/EPIA_Global_Market_Outlook_for_Photovo ltaics_2014-2018_-_Medium_Res.pdf.

[50] O. Schäfer, J. Watson, 'Global Market Outlook 2015-2019', http://helapco.gr/pdf/Global_Market_Outlook_2015_-2019_lr_v23.pdf.

[51] J. Stein, "4th PV Performance Modelling and Monitoring workshop Introduction', 4th PV Performance Modelling and Monitoring Workshop Report, Koln, 2015.

[52] M. S. Homscheidt, G. Gessel, L. Kluser, M. Kosmale, S. Jung, N. Killius, H. Ruf, G. Heilscher, 'Satelite and camera derived irradiance data for applications in low voltage grids with large PV shares', 4th PV Performance Modelling and Monitoring Workshop Report, Koln, 2015.

[53] F. Mavromatakis, F. Vignola, 'Spectral Corrections for PV Performance Modelling', 4th Performance Modelling and Monitoring Workshop Report, Koln, 2015.

[54] M. Lee, A. Panchula, 'Combined Air Mass and Precipitable Water Spectral Correction for PV Modelling', 4th PV Performance Modelling and Monitoring Workshop Report, Koln, 2015.

[55] Sika Services AG, 'Solar Solutions. New horizons in sealing and bonding for photovoltaics', 2015.

[56] Ulbrich Solar Technologies, 'Solar cell tabbing, interconnect wire and tinned copper flat wire for solar cell modules', 2015.

[57] SMA, 'Technology Compendium 3.4', Backgrounds, Requirements and SMA solutions, May 2012.

[58] 'Share of renewables in energy consumption in the EU rose further to $16 \%$ in 2014', http://ec.europa.eu/eurostat/documents/2995521/7155577/ 8-10022016-AP-EN.pdf/38bf822f-8adf-4e54-b9c6-87b342ead339, 30/2016, 10 February 2016. 


\section{Biographies}

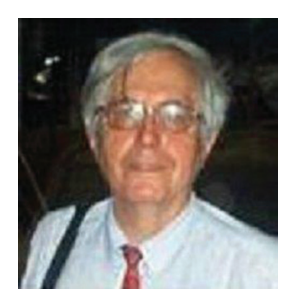

L. Fara is currently full Professor at University "Politehnica" of Bucharest, Faculty of Applied Sciences. He is the President of the Renewable Energy Commission of Romanian Academy. He is full member of Romanian Academy of Science (AOSR). He was involved in more than $15 \mathrm{EU}$ projects, as member or coordinator. He contributed to organization of several international conferences dedicated to renewable energy, the newest one being World Renewable Energy Congress (WREC) 2015. In the last two years, he was involved in two EU projects, MultiscaleSolar from COST and SOLHET from M-Era.net. He is coordinating several Ph.D. students in researching and modeling of solar cells and PV systems. His main interests are advanced solar cells, forecasting and modeling of PV systems, statistical models of solar radiation and energy efficiency applications. He published articles in ISI international journals, mainly dedicated to quantum well, polymer, dye-sensitized and silicon-based solar cells. He is author of about 200 conference, journal and book chapter publications. He coordinated as editor, together with Professor Masafumi Yamaguchi from Japan, the publication of the book "Advanced Solar Cell Materials, Technology, Modeling, and Simulation" at Hershey: IGI Global in 2013; he also contributed at several chapters of this book. He received the Romanian Academy award in Physics for his activity in solar energy in 1987, as well as the Romanian Academy of Science award in Physics for the book "Advanced Solar Cell Materials, Technology, Modeling, and Simulation" in 2015. 


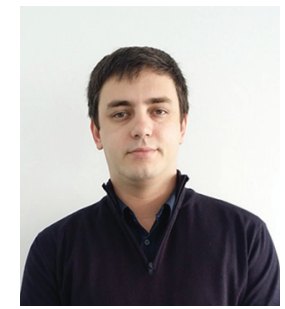

A. Diaconu received his B.Sc. degree in Physics Engineering at Faculty of Applied Sciences from University "Politehnica" of Bucharest in 2009 and his Masters degree in Photonics and Advanced Materials at Faculty of Applied Sciences from University "Politehnica" of Bucharest in 2011. He was admitted as a Ph.D. candidate in 2011. He prepared his Ph.D. thesis, entitled "Contributions to operational optimization of PV systems for applications", to be officially presented until the end of 2016. He was involved in three EU research and training projects (from IEEE, M-Era.net and COST). His main research interests include utilization of forecasting models of solar radiation for estimation of energy production of PV systems/parks, as well as PV systems modeling using advanced programs (S.A.M., Solarius-PV and PVsyst). He is author of a few international conference and journal publications.

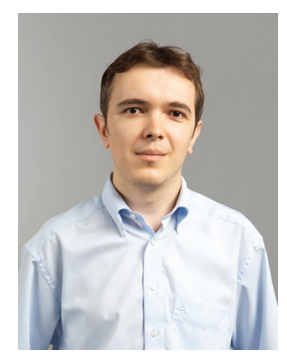

F. Dragan received his B.Sc. degree in Physics Engineering at Faculty of Applied Sciences from University "Politehnica" of Bucharest in 2011 and his Masters degree in Photonics and Advanced Materials at Faculty of Applied Sciences from University "Politehnica" of Bucharest in 2013. He was admitted as a Ph.D. candidate in 2013. He is currently preparing his Ph.D. thesis, entitled "Research and contributions concerning optical modeling and 


\section{L. Fara et al.}

numerical simulation of nanostructured solar cells". He was involved in two EU research projects (from M-Era.net and COST) dedicated to study and improvement of new types of third generation solar cells. His main research interests include optical modeling of advanced solar cells for efficiency improvement, using advanced software (Silvaco ATLAS). He is author of a few international conference and journal publications. 